\title{
CURE CHARACTERISTICS AND CROSSLINK DENSITY OF NATURAL RUBBER/STYRENE BUTADIENE RUBBER BLENDS
}

\author{
Indra Surya, Syahrul Fauzi Siregar \\ Department of Chemical Engineering, Engineering Faculty, University of Sumatera \\ Utara, Medan 20155, Sumatera Utara, Indonesia \\ E-mail: indradanas@yahoo.com
}

\begin{abstract}
By using a semi-efficient vulcanization system, the cure characteristics and crosslink density of natural rubber/styrene butadiene rubber (NR/SBR) blends were studied with a blend ratio from 0 to $100 \%$ rubber. The scorch time, optimum cure time, and torque difference value of the blended rubber compounds were determined by using the MovingDie Rheometer (MDR 2000). The crosslink density was determined by the Flory-Rehner approach. Results indicate that the scorch and cure times, $t_{2}$ and $t_{90}$, of the NR/SBR blends increased with increasing the SBR content. Whilst, the maximum values of torque difference and crosslink density were performed by the NR/SBR blend with a blend ratio of 75/25.
\end{abstract}

Keywords : Natural Rubber; Styrene Butadiene Rubber; Scorch time; Cure time; Torque difference, Crosslink density.

\begin{abstract}
Abstrak :
Dengan menggunakan sistim vulkanisasi semi-effisien, karakteristik pematangan dan kerapatan sambung silang dari kompon adonan-adonan Karet Alam/Karet Stirena Butadiena (KA/KSB) diamati. Rasio adonan adalah dari $0 \%$ ke $100 \%$ karet. Waktu skorj, waktu pematangan optimum, dan selisih tork dari adonan-adonan karet tersebut ditentukan dengan menggunakan Moving-Die Rheometer (MDR 2000). Kerapatan sambung silang diukur dengan menggunakan metode Flory - Rehner. Hasil pengamatan menunjukkan bahwa waktu skorj dan waktu pematangan optimum, $\mathrm{ts}_{2}$ and $\mathrm{t}_{90}$, meningkat dengan meningkatkan komposisi KSN di dalam adonan karet-karet tersebut. Nilai-nilai selisih tork dan kerapatan sambung silang yang maksimum diperoleh oleh adonan KA/KSB dengan rasio adonan $75 / 25$.
\end{abstract}

Kata kunci : Karet Alam; Karet Stirena Butadiena; Waktu skorj; Waktu pematangan optimum; Kerapatan sambung silang.

\section{Introduction}

In rubber technology, blending of some raw rubbers is an attempt to produce some new rubbery materials with a wide range of applications. The attempt takes some advantages of the attractive properties of the blend constituents while avoiding the economical and technical uncertainties associated with synthesising new rubbery materials $[6,13]$. The blending of two or more raw rubbers of different types is useful for the preparation of materials with properties absent in the rubber components $[9,11,14]$. Natural rubber (NR) and its blended compounds have been extensively studied because of their superior performance in a wide range of applications, especially in tire application. Natural rubber is prone to deterioration by ozone attack due to its highly unsaturated polymeric backbone. In general, improvement in the poor ozone resistance of NR can be achieved by blending it with low-unsaturation rubbers such as styrene butadiene rubber (SBR). SBR is obtained by polymerising styrene and butadiene with a relatively small amount of a non-conjugated diene, which usually imparts good resistance to aging, weathering and chemical resistance $[1,3,6]$.

In this study, NR was blended with SBR with some of blend ratios. The cure characteristics and crosslink density of blended NR/SBR compounds were studied. Cure characteristics of the blended rubber compounds were determined by using a Moving Die Rheometer which cured at $150{ }^{\circ} \mathrm{C}$, with, and the crosslink density was measured by the Flory-Rehner approach.

\section{Experimental \\ Materials}

Natural Rubber, and Styrene Butadiene Rubber were used. Other compounding ingredients were sulphur, zinc oxide, stearic acid, N-isopropyl-N'-phenyl-pphenylenediamine (IPPD), N-sikloheksil-2benzol tiazolsulfenamide (CBS). 


\section{Compounding}

A semi efficient vulcanization system was used for compounding. The recipe for the preparation of the NR/SBR blended compound is given in Table 1. The compounding procedure was done in accordance with the American Society for Testing and Material (ASTM) - Designation D 3184 - 80. Compounding was done on tworoll mill.

Table 1. A typical formulation of the blended rubber compounds

\begin{tabular}{|l|l|}
\hline Ingredients & ${\text { Content }(\mathrm{phr})^{\mathrm{a}}}^{\mathrm{a}}$ \\
\hline Rubber blend ${ }^{\mathrm{b}}$ & 100.0 \\
Zinc oxide & 5.0 \\
Stearic acid & 2.0 \\
IPPD & 2.0 \\
CBS & 1.5 \\
Sulphur & 1.5 \\
\hline \multicolumn{2}{|c|}{${ }^{\mathrm{a}}$ parts per hundred parts of rubber } \\
b Blend ratio for NR/SBR $(100 / 0,75 / 25$, \\
50/50, 25/75, and 0/100).
\end{tabular}

\section{Cure Characteristics}

The cure characteristics of the NR/SBR blended compounds were obtained using a Monsanto Moving Die Rheometer (MDR 2000), which was employed to determine the scorch time $\left(\mathrm{ts}_{2}\right)$, cure time $\left(\mathrm{t}_{90}\right)$ and torque difference $\left(\mathrm{M}_{\mathrm{H}}-\mathrm{M}_{\mathrm{L}}\right)$, according to ISO 3417 . Samples of the respective compounds were tested at $150^{\circ} \mathrm{C}$. The compounds were subsequently compression-moulded using a stainless steel mould at $150^{\circ} \mathrm{C}$, with a pressure of $10 \mathrm{MPa}$, and applying a laboratory hotpress based on respective curing times.

\section{Measurement of crosslink density}

Swelling tests on the rubber vulcanisates were performed in toluene in accordance with ISO 1817 . The cured test pieces $(30 \mathrm{~mm} \times 5$ $\mathrm{mm} \times 2 \mathrm{~mm}$ ) were weighed using an electrical balance and swollen in toluene until equilibrium, which took 72 hours at room temperature. The samples were taken out from the liquid, the toluene was removed from the sample surfaces and the weight was determined. The samples were then dried in the oven at $60^{\circ} \mathrm{C}$ until constant weights were obtained. The swelling results were used to calculate the molecular weight between two crosslinks $\left(M_{c}\right)$ by applying the Flory-Rehner Equation [8].

$$
\begin{aligned}
& M_{c}=\frac{-\rho_{p} V_{s} V_{r}^{1 / 3}}{\ln \left(1-V_{r}\right)+V_{r}+\chi V_{r}^{2}} \\
& V_{r}=\frac{1}{1+Q_{m}}
\end{aligned}
$$

where $\rho$ is the rubber density ( $\rho$ of $\mathrm{NR}=0.92$ $\left.\mathrm{g} / \mathrm{cm}^{3}\right), V_{s}$ is the molar volume of the toluene $\left(V_{s}=106.4 \mathrm{~cm}^{3} / \mathrm{mol}\right), V_{r}$ is the volume fraction of the polymer in the swollen specimen, $Q_{m}$ is the weight increase of the blends in toluene and $\chi$ is the interaction parameter of the rubber network-solvent ( $\chi$ of $\mathrm{NR}=0.393)$. The degree of the crosslink density is given by;

$V_{c}=\frac{1}{2 M_{c}}$

\section{Results And Discussion \\ The cure characterisics}

The scorch and cure times of NR/SBR blends are shown in Figure 1. The scorch and cure times of NR/SBR blended compounds increased with increasing the content of SBR in the rubber blends. According to Chouch and Chang [7,12], the cure rate of a rubber compound depends on the number of allylic hydrogen atoms in the statistical repeat unit, whereby a higher content of allylic hydrogen resulted in a lower overall apparent activation energy of curing, thus increasing the speed of the cure rate. Therefore, longer scorch and cure times were attributed to a lower allylic hydrogen content of the blended rubber compounds. Generally, a statistical repeated unit of NR and SBR have 7 and 3.3 allylic hydrogen atoms, respectively [12]. 


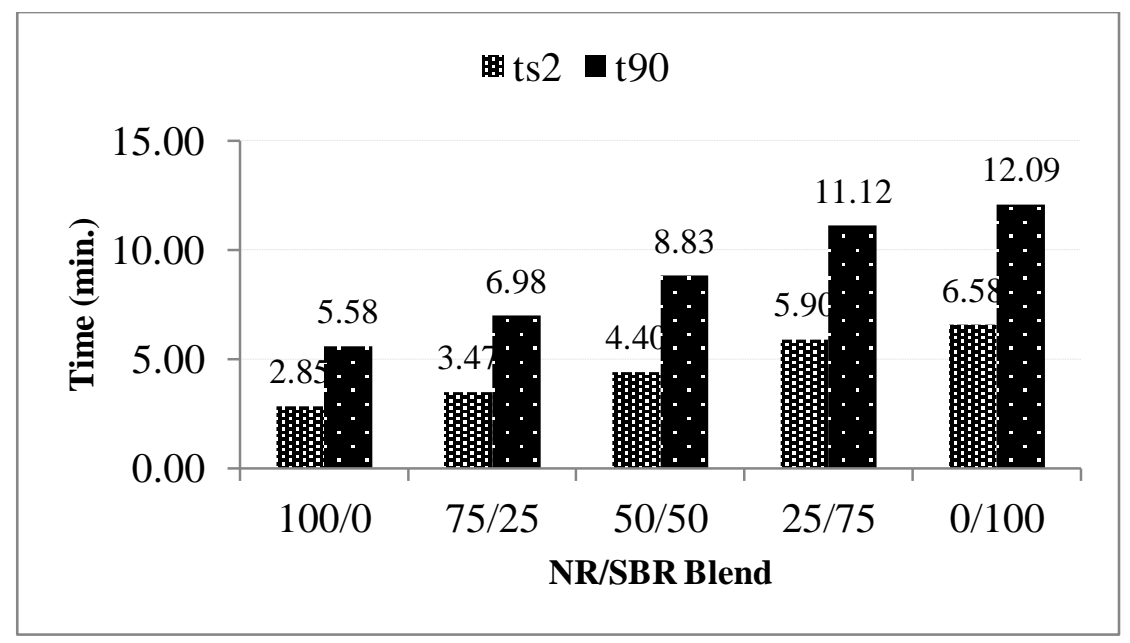

Figure 1. Scorch and cure times of NR/SBR blended compound

Figure 2 shows the torque difference $\left(\mathrm{M}_{\mathrm{H}}-\mathrm{M}_{\mathrm{L}}\right)$ of the NR/SBR blended compounds. A 75/25 NR/SBR blended compound has the highest value of torque difference.

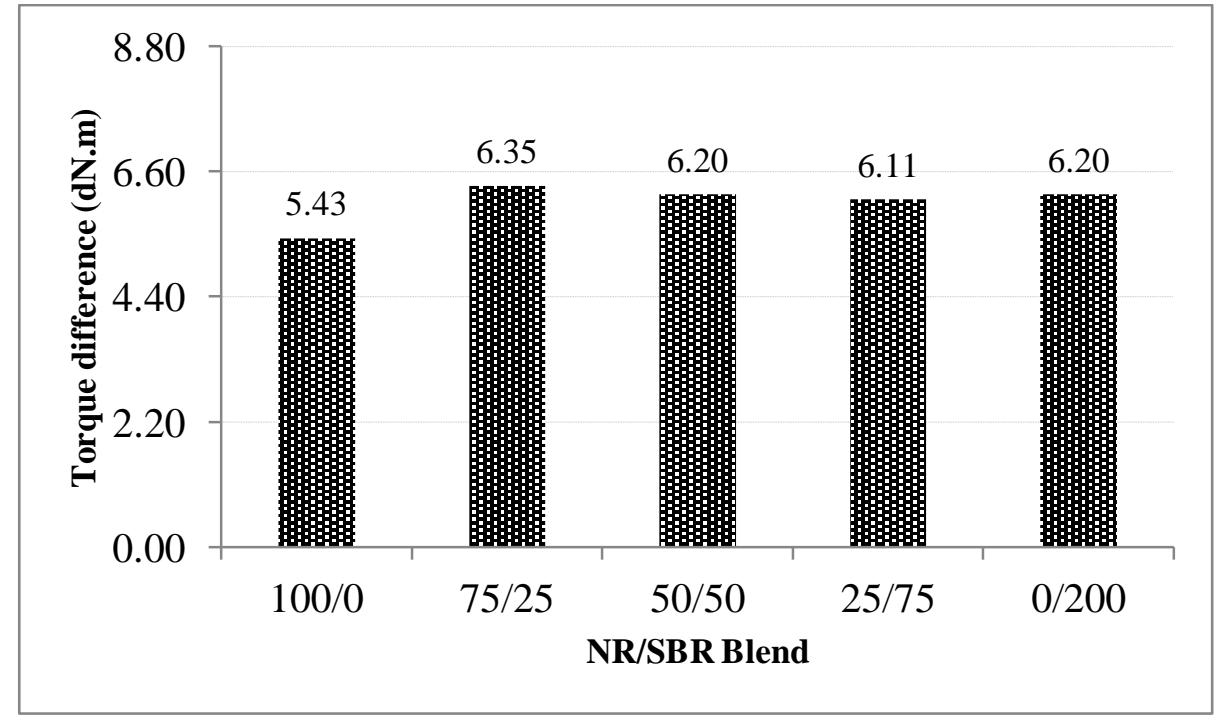

Figure 2. Torque difference of NR/SBR blended compound

\section{The crosslink density}

The crosslink densities of the vulcanisates NR/SBR blend were determined by the Flory-Rehner approach [Eq. (1)]. Figure 3 shows the crosslink density of the rubber blended vulcanisates at room temperature. The 75/25 NR/SBR blended rubber compound has the highest degree of crosslink. It can be attributed to the synergetic effect of both raw rubbers, NR and SBR. This result is in line with Figure 2. The 75/25 NR/SBR blended rubber compound exhibited the highest value of torque difference. Based on theory, torque difference indicates the degree of crosslink density of a rubber compound $[2,4,5,10]$. The greater the value, the higher is the crosslink density. 


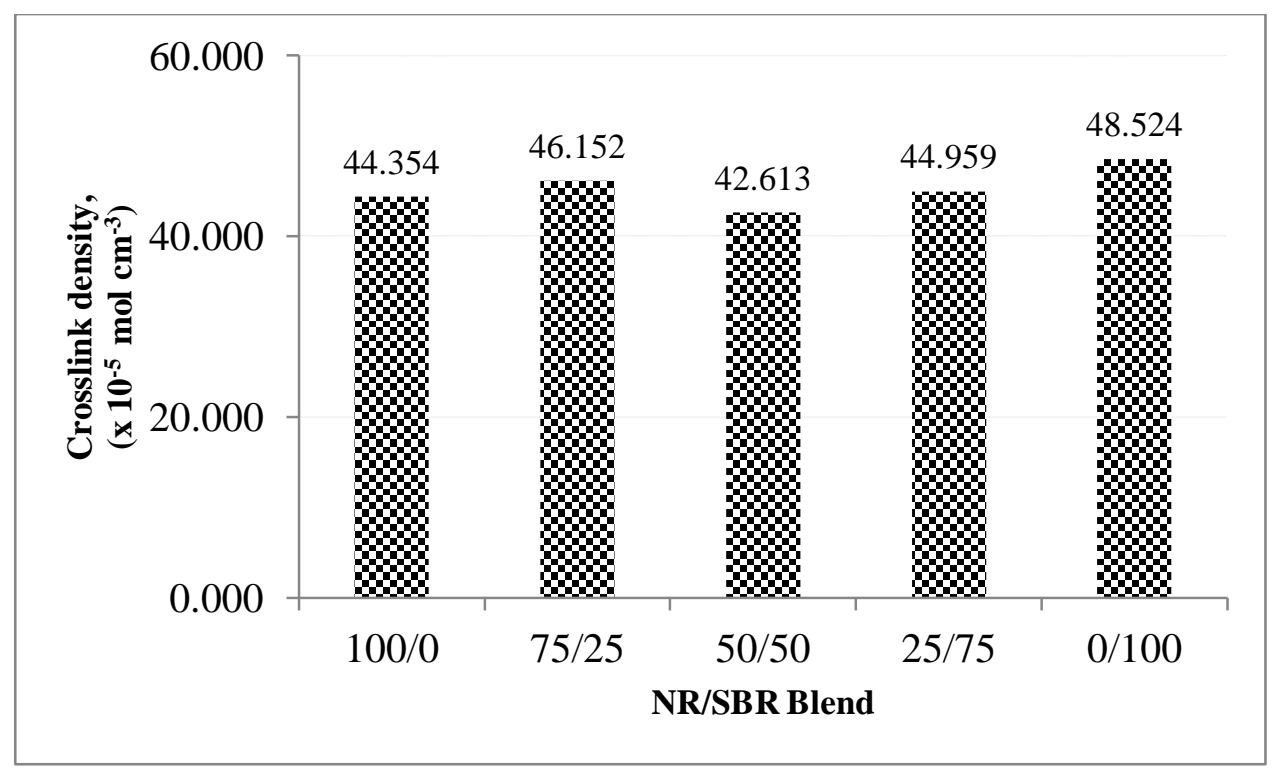

Figure 3. Crosslink density of NR/SBR blended vulcanisate

\section{Conclusions}

From this study, the following conclusions can be drawn:

1. The scorch and cure times of natural rubber/styrene butadiene blended compound increase with increasing the content of styrene butadiene rubber.

2. A $75 / 25$ blend ratio is the optimum blend ratio of natural rubber/styrene butadiene rubber blend which produced the maximum values of torque difference and crosslink density.

\section{Acknowledgements}

The authors would like to thank Directorate General of Higher Education Ministry of Education and Culture of Republic Indonesia for Research Grant, under Penelitian Hibah Bersaing scheme, with Contract No. 4804/UN5.1.R/KEU/2014.

\section{References}

[1] A. Kumar, G. Dipak, K. Basu, Natural rubber-ethylene propylene diene rubber covulcanization: Effect of reinforcing fillers, J. Appl. Polym. Sci. 84 (2002) 1001-1010.

[2] B. Boonstra, H. Cochrane, E. Dannenberg, Reinforcement of silicone rubber by particulate silica, Rubber Chemistry and Technology, 48 (1975) 558-576.

[3] F. Delor-Jestin, J. Lacoste, N. BarroisOudin, C. Cardinet, J. Lemaire, Photo-, thermal and natural ageing of ethylenepropylene-diene monomer (EPDM) rubber used in automotive applications.
Influence of carbon black, crosslinking and stabilizing agents, Poly. Degrad. Stab. 67 (2000) 469-477.

[4] H. Cochrane, C. Lin, The influence of fumed silica properties on the processing, curing, and reinforcement properties of silicone rubber, Rubber Chemistry and Technology, 66 (1993) 48-60.

[5] H. Ismail, C. Ng, Palm oil fatty acid additives (POFA's): Preparation and application, Journal of Elastomers and Plastics, 30 (1998) 308-327.

[6] H. Nabil, H. Ismail, A. Azura, Compounding, mechanical and morphological properties of carbon-blackfilled natural rubber/recycled ethylenepropylene-diene-monomer (NR/REPDM) blends, Polymer Testing, 32 (2013) 385-393.

[7] H. Ismail, S. Shaari, N. Othman, The effect of chitosan loading on the curing characteristics, mechanical and morphological properties of chitosanfilled natural rubber (NR), epoxidised natural rubber (ENR) and styrenebutadiene rubber (SBR) compounds, Polymer Testing, 30 (2011) 784-790.

[8] P.J. Flory, J. Rehner Jr., Statistical mechanics of crosslinked polymer networks II. Swelling, J. Chem. Phys., 11 (1943) 521.

[9] P. Sae-oui, C. Sirisinha, U. Thepsuwan, P. Thapthong, Influence of accelerator type on properties of NR/EPDM blends, Polym. Test. 26 (2007) 1062-1067.

[10] P. Teh, Z. Mohd Ishak, A. Hashim, J. Karger-Kocsis, U. Ishiaku, Effects of 
epoxidized natural rubber as a compatibilizer in melt compounded natural rubber-organoclay nanocomposites, European Polymer Journal, 40 (2004) 2513-2521.

[11] S. H. El-Sabbagh, Compatibility study of natural rubber and ethylene-propylenediene rubber blends, J. Appl. Polym. Science. 90 (2003) 1-11.

[12] S.H. Chough, D.H. Chang, Kinetics of sulfur vulcanization of NR, BR, SBR, and their blends using a rheometer and DSC, Journal of Applied Polymer Science, 61 (1996) 449-454.

[13] W. Arayapranee, G. Rempel, Properties of NR/EPDM blends with or without methyl methacrylate-butadiene-styrene (MBS) as a compatibilizer, Intern. J. Mater. Struc. Relia. 5 (2007) 1-12.

[14] Y.W. Chang, Y.S. Shin, H. Chun, C. Nah, Effects of trans-polyoctylene rubber (TOR) on the properties of NR/EPDM blends, J. Appl. Polym. Sci. 73 (1999) 749-756. 